\title{
Colchicine in the treatment of the inflammatory phase of Graves' ophthalmopathy: a prospective and randomized trial with prednisone
}

\author{
Colchicina no tratamentoda fase inflamatória da oftalmopatia de Graves: \\ um estudoprospectivoe randomizadocom prednisona
}

\author{
Francisco José da Cunha Stamato ${ }^{1}$ \\ Rui Monterio de Barros Maciel $^{2}$ \\ Paulo Gois Manso ${ }^{3}$ \\ Ângela Maria Borri Wolosker ${ }^{4}$ \\ Elias Rodrigues de Paiva ${ }^{5}$ \\ Antonio Carlos Lopes ${ }^{6}$ \\ Reinaldo Perrone Furlanetto ${ }^{7}$
}

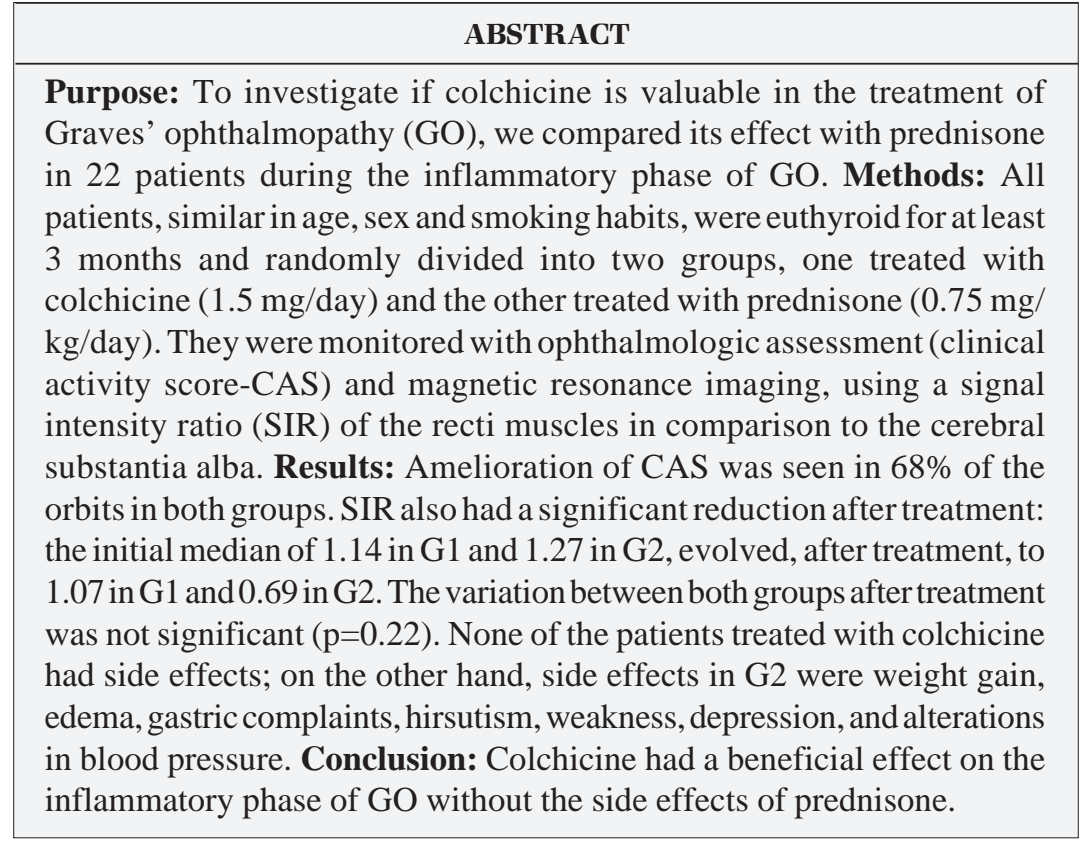

Keywords: Graves ophthalmopathy/drug therapy; Colchicine/therapeutic use; Prednisone/ adverse effects; Smoking; Prospective studies
Departments of Medicine, Ophthalmology, Radiology and Biostatistics, and the Orbital Center, Universidade Federal de São Paulo - UNIFESP - São Paulo (SP) - Brazil.

${ }^{1}$ Doutor em Medicina pelo curso de Pós-Graduação da Universidade Federal de São Paulo - UNIFESP - São Paulo (SP) - Brasil.

${ }^{2}$ Professor Titular da Disciplina de Endocrinologia da UNIFESP - São Paulo (SP) - Brasil.

${ }^{3}$ Mestre em Oftalmologia pelo curso de Pós-Graduação do Departamento de Oftalmologia da UNIFESP - São Paulo (SP) - Brasil.

${ }^{4}$ Doutora em Medicina pelo curso de Pós-Graduação do Departamento de Diagnóstico por Imagem da UNIFESP São Paulo (SP) - Brasil.

${ }^{5}$ Professor Adjunto da UNIFESP - São Paulo (SP) - Brasil.

${ }^{6}$ Professor Titular da Disciplina de Clínica Médica da UNIFESP - São Paulo (SP) - Brasil.

Professor Adjunto da Disciplina de Endocrinologia da UNIFESP - São Paulo (SP) - Brasil.

Address to correspondence: Francisco Stamato. Division of Endocrinology, Department of Medicine Universidade Federal de São Paulo. Alameda Jaú, 310/91 - São Paulo (SP) CEP 01420-000

E-mail: franstamato@hotmail.com

Recebido para publicação em 14.03.2006

Aprovação em 17.05.2006

Nota Editorial: Depois de concluída a análise do artigo sob sigilo editorial e com a anuência do Dr. Roberto Abucham sobre a divulgação de seu nome como revisor, agradecemos sua participação neste processo.

\section{INTRODUCTION}

Graves' ophthalmopathy (GO) is a chronic autoimmune process that affects the orbital tissues and it is generally associated with Graves' thyroid disease. As other autoimmune diseases, GO is multifactorial and dependent upon the interaction among environmental, genetic and endogenous factors ${ }^{(1-2)}$. Smoking is the most clearly identified risk factor, and there is an association between the severity of the disease and the amount of smoked cigarettes ${ }^{(1-2)}$. During the inflammatory stage of the disease, there is an infiltration of the orbital tissues by lymphocytes and macrophages ${ }^{(1-3)}$, with release of several cytokines, mostly interleukin 1 (IL-1), tumor necrosis factor- $\alpha$ (TNF- $\alpha$ ) and inte- $\gamma$ (IFN- $\gamma$ ), that induces the production of glycosaminoglycans by fibroblasts. In later stages, fibrosis with restriction and atrophy of the extraocular muscles accounts for the clinical dysfunction ${ }^{(1)}$.

Colchicine is an alkaloid that has been used for an increasing number of diseases due to its anti-inflammatory effects ${ }^{(4-5)}$; it reduces motility, chemo- 
812 Colchicine in the treatment of the inflammatory phase of Graves' ophthalmopathy:

a prospective and randomized trial with prednisone

taxis, phagocytosis and adhesiveness of polymorphonuclear cells, as well as the activity of proinflammatory enzymes ${ }^{(6-9)}$. In addition, it decreases the production of TNF- $\alpha$ and TNF- $\alpha$ mRNA levels, the expression of adhesion molecules and IL-2 receptors and the synthesis of IL- $6^{(10-14)}$. Furthermore, it inhibits the production of IL-1 by neutrophils and induces an increased IL-1 production by macrophages ${ }^{(15-16)}$. It is also a potent inhibitor of fibroblast and lymphocyte functions and proliferation $^{(14)}$.

Corticosteroids are the first-choice immunosuppressive treatment for GO, but cause important side effects ${ }^{(17)}$. To investigate if colchicine could be an appropriate therapy for patients with inflammatory GO due to its good tolerability and possible action on GO etiological factors, we performed this prospective and randomized study to compare its efficacy and side effects with those of oral prednisone.

\section{METHODS}

\section{Patients}

Twenty-five patients with untreated and active inflammatory stage of the eye disease, GO classes II-IV ${ }^{(18)}, 16$ females and 9 males aged 23 to 66 years (median 41 years) were admitted to the Orbital Center of "Hospital São Paulo", a teaching hospital of the Federal University of São Paulo, in São Paulo, Brazil from 1999 to 2000. All patients had GO of less than 18 months of duration and were euthyroid for at least 3 months (independently of the type of treatment for the thyroid disease - Table 1), as indicated by physical examination and normal values of serum free thyroxine (fT4: 0.6-1.5 ng/dL; Delfia fluoroimmunoassay IFMA) and thyrotropin (TSH: 0.3-5 mU/L; IFMA).

\section{Methods}

Ophthalmologic evaluation and magnetic resonance imaging (MRI).

The GO activity was evaluated by the clinical activity score (CAS) suggested by Mourits et al. ${ }^{(19)}$, and by the signal intensity of the extraocular muscles (superior, medial, inferior and lateral) on MRI. This signal intensity was measured and expressed as a ratio (SIR) between extraocular muscles and cerebral substantia alba ${ }^{(20-21)}$. MRI was performed in coronal planes T2 using a $1.0 \mathrm{~T}$ superconducting MR unit gyroscan T10-NT (Philips). To evaluate the results obtained after treatment we have chosen the two more involved muscles. Patients and physicians who assigned the pre- and post-treatment CAS and MRI scans were blinded regarding the treatment group. Patients with optic neuropathy, diabetes mellitus, hypertension, hepatic and kidney disease, or gastrointestinal complaints were not included. Patients with insufficient follow-up, or who developed abnormal thyroid function during the study were excluded. The trial was approved by the Committee of Medical Ethics of our institution and a written informed consent was obtained from all patients.

\section{Treatment and follow-up}

Patients were randomized by random permuted blocks (blocking) in two groups ${ }^{(22-23)}$. Group $1(\mathrm{G} 1, \mathrm{n}=12)$ was treated with a single oral dose of colchicine $1.5 \mathrm{mg} / \mathrm{day}$ for $1 \mathrm{month}$ and thereafter with a dose of $1.0 \mathrm{mg} / \mathrm{day}$ for 2 more months. Group $2(\mathrm{G} 2, \mathrm{n}=13)$ received oral prednisone $0.75 \mathrm{mg} / \mathrm{kg} /$ day for 1 month and, subsequently, decreasing doses for 2 more months. Both groups were similar regarding age, sex and smoking habits (Table 1). Both drugs were supplied to the patients to obtain better compliance. Follow-up examinations were performed at the beginning of the treatment and 1 and 3 months after. Routine laboratory tests were performed monthly. One patient in G1 was excluded due to the development of hypothyroidism during the period of the study. Two patients in G2 were excluded due to side effects of prednisone (hypertension, weight gain and edema).

To assess the efficacy of both forms of treatment the patients were evaluated by measuring CAS and MRI before and three months after the therapy. The success of each form of treatment was defined as a decrease in CAS from inflammatory $(\geq 4)$ to stable $(\leq 3)$ and a reduction of the signal intensity ratio on MRI.

\section{Statistical analysis}

The CAS and SIR results were analyzed with the GraphPad InStat (Instat Inc., USA) software package V2.02. For sta-

\begin{tabular}{|c|c|c|c|c|}
\hline Patient & Age & Sex & $\begin{array}{l}\text { Treatment for } \\
\text { thyroid disease }\end{array}$ & $\begin{array}{l}\text { Smoking } \\
\text { habits }\end{array}$ \\
\hline \multicolumn{5}{|c|}{ Group 1 - Colchicine } \\
\hline 1 & 41 & Female & Metimazole + I-thyroxine & Yes \\
\hline 2 & 25 & Male & Radioiodine & No \\
\hline 3 & 40 & Male & I-thyroxine after Radioiodine & No \\
\hline 4 & 35 & Male & I-thyroxine after Radioiodine & No \\
\hline 5 & 42 & Male & Euthyroidism & Yes \\
\hline 6 & 48 & Female & Metimazole & Yes \\
\hline 7 & 58 & Female & Remission of hyperthyroidism & No \\
\hline 8 & 58 & Female & Metimazole & Yes \\
\hline 9 & 66 & Male & Propiltiouracil + I-thyroxine & No \\
\hline 10 & 44 & Female & Remission of hyperthyroidism & Yes \\
\hline 11 & 51 & Female & L-thyroxine after thyroidectomy & Yes \\
\hline \multicolumn{5}{|c|}{ Group 2 - Prednisone } \\
\hline 12 & 49 & Female & Remission of hyperthyroidism & Yes \\
\hline 13 & 53 & Female & I-thyroxine after thyroidectomy & No \\
\hline 14 & 31 & Female & Euthyroidism & Yes \\
\hline 15 & 32 & Female & I-thyroxine after Radioiodine & Yes \\
\hline 16 & 55 & Male & Metimazole & No \\
\hline 17 & 35 & Female & Euthyroidism & Yes \\
\hline 18 & 31 & Female & I-thyroxin after Metimazole & Yes \\
\hline 19 & 43 & Female & I-thyroxin after thyroidectomy & No \\
\hline 20 & 52 & Female & Euthyroidism & No \\
\hline 21 & 23 & Male & I-thyroxine after thyroidectomy & No \\
\hline 22 & 24 & Male & Euthyroidism & No \\
\hline
\end{tabular}


tistical analysis of the treatment outcome by CAS, only data of inflamed orbits ( $C A S \geq 4)$ were considered. For the SIR evaluation we selected the two more inflamed muscles. The MannWhitney test was used for comparison between groups and between smokers and non-smokers before treatment. Pre- and post-treatment values were compared by the one-tailed Wilcoxon rank sum test. Fisher's exact probability test was used for the analysis of effectiveness between groups. To compare the percentage of variation we used the one-tailed MannWhitney test. For all tests $p \leq 0.05$ was considered significant.

\section{RESULTS}

All 22 patients remained euthyroid during the study showing normal values of serum fT4 and TSH. At the end of the treatment all of them showed symptomatic relief and improvement in appearance.

The initial median CAS in G1 was 5.0 and, after treatment, was altered to 3.0. Similarly, in G2, the initial median CAS was 4.0 and, after treatment, was changed to 1.0. Therefore, under both treatments, a significant reduction in CAS was observed ( $p<0.0001$ for $\mathrm{G} 1$ and $\mathrm{p}=0.0003$ for G2, Table 2 and Figure 1 ). After 3 months the therapeutic effect was similar in both groups, with 13 of 18 orbits (72\%) with inflammatory disease in G1 responding to colchicine and 16 of 17 orbits (94\%) in G2 responding to prednisone $(\mathrm{p}=0.12)$. When we considered a more strict outcome, the improvement of at least 2 points in CAS of all orbits, 15 orbits in G1 (68\%) and 15 orbits in G2 (68\%) showed amelioration of disease activity and, again, the therapeutic effect was identical in both groups.

The evaluation of SIR revealed a significant reduction after treatment in both groups (Table 2 and Figure 2). Thus, the initial median SIR in G1 was 1.14 and, after treatment, changed to 1.07 $(\mathrm{p}=0.01)$. The initial median in $\mathrm{G} 2$ was 1.27 and, after treatment, was modified to $0.67(\mathrm{p}=0.01)$. There was no statistical diffe-

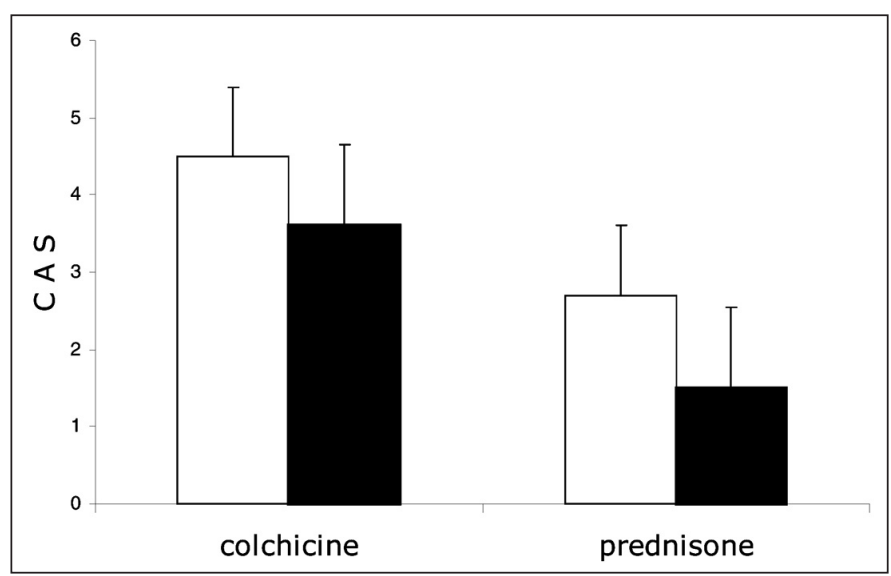

Figure 1 - Comparison of the clinical activity score (CAS) of patients with Graves' ophthalmopathy before (white bars) and after treatment (black bars) with colchicine $(n=11)$ or prednisone $(n=11)$; under both treatments, a significant reduction in CAS was observed $(p<0.0001$ for $G 1^{\star}$ and $p=0.0003$ for $G 2^{\star *}$ ) rence in the initial SIR between both groups $(\mathrm{p}=0.80)$. In addition, the percentage of variation between groups was also not significant, $\mathrm{G} 1=0.16$ and $\mathrm{G} 2=0.38(\mathrm{p}=0.22)$.

None of the patients in G1 had side effects with the employed dose of colchicine. On the other hand, in G2, besides

\begin{tabular}{|c|c|c|c|c|c|}
\hline Patient & Orbit & $\begin{array}{c}\text { CAS } \\
\text { before } \\
\text { treatment }\end{array}$ & $\begin{array}{c}\text { CAS } \\
\text { after } \\
\text { treatment }\end{array}$ & $\begin{array}{c}\text { SIR } \\
\text { before } \\
\text { treatment }\end{array}$ & $\begin{array}{c}\text { SIR } \\
\text { after } \\
\text { treatment }\end{array}$ \\
\hline \multicolumn{6}{|c|}{ Group 1 - Colchicine } \\
\hline \multirow[t]{2}{*}{1} & Right & 6 & 3 & 1.13 & 0.74 \\
\hline & Left & 2 & 1 & 0.98 & 0.49 \\
\hline \multirow[t]{2}{*}{2} & Right & 4 & 2 & 1.15 & 0.94 \\
\hline & Left & 5 & 3 & 0.99 & 1.05 \\
\hline \multirow[t]{2}{*}{3} & Right & 4 & 0 & 0.88 & 0.77 \\
\hline & Left & 0 & 0 & 0.79 & 0.75 \\
\hline \multirow[t]{2}{*}{4} & Right & 5 & 2 & & \\
\hline & Left & 5 & 3 & & \\
\hline \multirow[t]{2}{*}{5} & Right & 5 & 2 & 1.27 & 1.04 \\
\hline & Left & 8 & 5 & 1.29 & 1.08 \\
\hline \multirow[t]{2}{*}{6} & Right & 4 & 3 & 1.10 & 1.14 \\
\hline & Left & 5 & 3 & 1.23 & 1.31 \\
\hline \multirow[t]{2}{*}{7} & Right & 5 & 3 & 1.98 & 1.68 \\
\hline & Left & 4 & 3 & 2.09 & 1.74 \\
\hline \multirow[t]{2}{*}{8} & Right & 6 & 5 & 1.62 & 1.60 \\
\hline & Left & 6 & 4 & 1.53 & 1.31 \\
\hline \multirow[t]{2}{*}{9} & Right & 5 & 2 & & \\
\hline & Left & 3 & 2 & & \\
\hline \multirow[t]{2}{*}{10} & Right & 7 & 4 & 1.02 & 1.18 \\
\hline & Left & 7 & 5 & 0.83 & 0.93 \\
\hline \multirow[t]{2}{*}{11} & Right & 3 & 2 & & \\
\hline & Left & 4 & 2 & & \\
\hline \multicolumn{6}{|c|}{ Group 2 - Prednisone } \\
\hline \multirow[t]{2}{*}{12} & Right & 5 & 1 & 1.14 & 0.69 \\
\hline & Left & 2 & 1 & 0.80 & 1.09 \\
\hline \multirow[t]{2}{*}{13} & Right & 4 & 1 & 1.39 & 0.50 \\
\hline & Left & 4 & 1 & 1.39 & 0.36 \\
\hline \multirow[t]{2}{*}{14} & Right & 4 & 1 & & \\
\hline & Left & 0 & 0 & & \\
\hline \multirow[t]{2}{*}{15} & Right & 3 & 2 & 0.74 & 0.58 \\
\hline & Left & 4 & 1 & 0.69 & 0.77 \\
\hline \multirow[t]{2}{*}{16} & Right & 5 & 3 & 1.91 & 1.59 \\
\hline & Left & 4 & 2 & 1.74 & 1.20 \\
\hline \multirow[t]{2}{*}{17} & Right & 4 & 1 & & \\
\hline & Left & 1 & 0 & & \\
\hline \multirow[t]{2}{*}{18} & Right & 5 & 3 & & \\
\hline & Left & 5 & 3 & & \\
\hline \multirow[t]{2}{*}{19} & Right & 4 & 1 & 2.03 & 0.62 \\
\hline & Left & 4 & 1 & 1.95 & 0.64 \\
\hline \multirow[t]{2}{*}{20} & Right & 5 & 2 & & \\
\hline & Left & 4 & 4 & & \\
\hline \multirow[t]{2}{*}{21} & Right & 3 & 2 & 0.43 & 0.63 \\
\hline & Left & 4 & 1 & 0.69 & 0.74 \\
\hline 22 & Right & 5 & 3 & & \\
\hline & Left & 0 & 0 & & \\
\hline
\end{tabular}


814 Colchicine in the treatment of the inflammatory phase of Graves' ophthalmopathy:

a prospective and randomized trial with prednisone

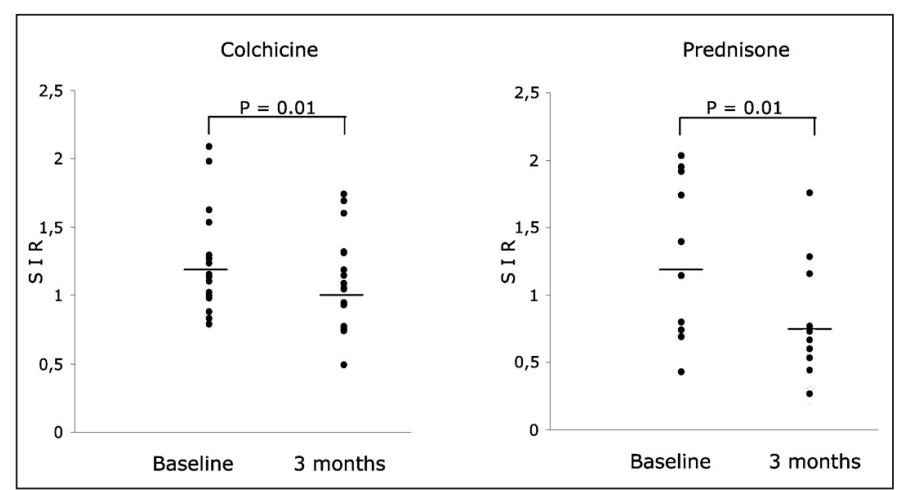

Figure 2 - Comparison of the signal intensity ratio (SIR) of the two more inflamed orbital muscles of patients with Graves' ophthalmopathy before and after treatment with colchicine (G1) or prednisone (G2); under both treatments a significant reduction of SIR was observed $(p=0.01$ for colchicine-treated group and $p=0.01$ for prednisone-treated group)

those 2 patients excluded due to adverse reactions, there were additional side effects related to prednisone, as weight gain (3 patients), edema (3 patients), gastric complaints (2 patients), hirsutism (1 patient), weakness (1 patient), depression (1 patient), and hypertension (4 patients).

On comparison between smokers and nonsmokers, independently of the treatment, there was a tendency for nonsmokers to present lower values of initial CAS ( $\mathrm{p}=0.08)$. Additionally, 10 of 15 orbits with inflammatory disease in smokers (66\%) responded to treatment, when compared with 18 of 19 orbits of nonsmokers $(94 \%)$, but this is not statistically significant $(\mathrm{p}=0.06)$.

\section{DISCUSSION}

Graves' ophthalmopathy can be an incapacitating eye disease in the most severe cases, causing disfiguring proptosis, pain, redness, swelling of the eyelids, grittiness of the eyes, diplopia, and even blindness ${ }^{(1,24)}$. In the active phase, lymphocytic infiltration and secretion of various cytokines induce glycosaminoglycan (GAG) production by fibroblasts ${ }^{(25-26)}$. Due to their hydrophilic nature, GAG contribute to interstitial edema and swelling of the orbital tissue in GO, leading to the clinical expression of the disease ${ }^{(27)}$.

Anti-inflammatory treatment can be applied in the active stage. The most used treatments are corticosteroids, radiotherapy or a combination of both. The success rate of corticosteroid therapy is $65 \%$, but this is achieved at the cost of significant morbidity. Almost one-third of the patients will experience the well-known and frequent side effects of this kind of treatment; and exacerbation following withdrawal is frequent ${ }^{(17,28)}$. Radiotherapy appears to be effective in some centers ${ }^{(29)}$, but without beneficial therapeutic effect in others ${ }^{(30-31)}$. There are other options for the treatment of $\mathrm{GO}$, with similar response rates, but seldomly indicated, as immunoglobulins, cyclosporine A, octreotide, azathioprine, cyclophosphamide and pentoxyfylline $\mathrm{e}^{(2,28,32)}$. Another suggestion is the use of antagonists of cytokines ${ }^{(26,33-36)}$, since there is evidence that citokynes, i.e., IL-1, IL-2, IL-4, IL-5, IL-10, interferon- $\gamma$ and TNF- $\alpha$, produced by orbital macrophages and fibroblasts or by infiltrating activated lymphocytes, are potent stimulators of GAG synthesis and other immunomodulatory proteins, like intercellular adhesion molecules and heat shock protein-72)(33-36). However, their practical use in chronic disease states is limited by the need to deliver these proteins parenterally. Additionally, studies are required to establish the safety, effectiveness, and the favorable cost-benefit ratio of these agents ${ }^{(33-36)}$.

In this prospective and randomized trial, colchicine was used for the first time in the treatment of the inflammatory phase of GO and its effect compared with prednisone, the drug considered to be the first choice in the treatment of this disease. Patients were euthyroid throughout the period of observation, and an interval of 3 months between therapy and assessment of therapeutic outcome was observed, in order to make spontaneous improvement less likely.

The response to therapy in GO is difficult to assess; as a result, several parameters have been evaluated. Among them, it is reported that a higher $\mathrm{T} 2$ relaxation time indicates inflammation rather than fibrosis and that the cause of the elevated $\mathrm{T} 2$ relaxation time is due to the increased water content of the retroorbital tissues ${ }^{(17)}$. In this trial we used the combination of the clinical activity score (CAS) ${ }^{(18-19)}$ and the signal intensity ratio on MRI (SIR) ${ }^{(20-21)}$ and showed that the therapeutic outcome in patients after 3 months of colchicine was equally effective and better tolerated than prednisone, with $72 \%$ of orbits responding to colchicine. Considering an improvement of at least 2 points in CAS, $68 \%$ of orbits showed amelioration of activity of the disease. Furthermore, of considerable importance is the fact that all patients receiving colchicine did not present side effects; on the other hand, there were complaints related to steroids in six prednisone-treated patients, besides those two patients initially excluded from the trial. The evaluation of signal intensity ratio on MRI after treatment also revealed a significant reduction in both groups; in G1 the therapeutic outcome was effective, demonstrating that colchicine is a valuable agent in the reduction of soft tissue inflammation.

The sites where colchicine might act include chemotaxis, phagocytosis, adherence of polymorphonuclear cells, fibroblast proliferation and collagen synthesis rate, as well as inhibition of cytokines (e.g. IL-1, IL-6, TNF- $\alpha$, TGF- $\beta)^{(8-9,37-38)}$. Furthermore, colchicine also downregulates the surface expression of intercellular adhesion molecule- $1^{(39)}$. The inhibition of leukocyte adhesion, fibroblast proliferation and cytokine release may cause a reduction of GAG secretion and an inhibition of the inflammatory cascade.

In this study, the smokers, as expected, had more severe ophthalmopathy than the nonsmokers. Smoking can decrease immunosuppression, allowing greater expression of the autoimmune process ${ }^{(40-41)}$. Our results, comparing smokers and nonsmokers, independently of the used drug, indicate that there was a tendency for nonsmokers to present lower values 
of initial CAS ( $\mathrm{p}=0.08)$. In addition, 10 of 15 smokers $(66 \%)$ were considered responders, compared with 18 of 19 (94\%) nonsmokers; although there was not a significant statistical difference, the nonsmokers showed a higher percentage of cure of inflammation. Since the value of $\mathrm{p}=0.06$ is very close to the critical rate, this can suggest a tendency of a higher probability of cure among nonsmokers, as it has been the experience of others ${ }^{(2)}$.

In conclusion, colchicine had a beneficial effect on the inflammatory phase of Graves' ophthalmopathy, providing symptomatic relieve, reduction of clinical activity score and signal intensity ratio; in addition, in this study it was equally effective when compared to the classic treatment with corticosteroids, but safer and better tolerated and did not present side effects when used in the proposed dose. Therefore, it is a new option for patients with $\mathrm{GO}$ and can be used for a prolonged time, avoiding recurrence of the disease.

\section{RESUMO}

Objetivo: Investigar se a colchicina é eficaz no tratamento da oftalmopatia de Graves, nós comparamos o seu efeito com a prednisona em 22 pacientes tratados na fase inflamatória da doença. Métodos: Todos os pacientes, similares quanto à idade, sexo e hábitos de tabagismo, estavam em eutiroidismo por pelo menos três meses e foram randomizados em dois grupos. O grupo 1 (G1) recebeu colchicina (1,5 mg/dia) e o grupo 2 (G2) foi tratado com prednisona $(0,75 \mathrm{mg} / \mathrm{kg} / \mathrm{dia})$. Os pacientes foram acompanhados com avaliação oftalmológica (escore de atividade clínica - CAS) e de imagem por meio da ressonância magnética, usando a relação da intensidade de sinal (SIR) dos músculos reto em comparação com a substância alba cerebral. Resultados: Diminuição no CAS de $68 \%$ foi notada em ambos os grupos. A SIR também apresentou redução significante após o tratamento: A mediana inicial do G1 de 1,14 e 1,27 do G2 diminui após o tratamento para 1,07 no G1 e 0,69 no G2. A variação entre os grupos após o tratamento não foi significante $(\mathrm{p}=0,22)$. Nenhum paciente tratado com colchicina apresentou efeito colateral; ao passo que os efeitos colaterais no G2 foram ganho de peso, edema, queixas gástricas, fraqueza, depressão e alteração na pressão arterial. Conclusão: A colchicina apresenta efeitos benéficos na fase inflamatória da oftalmopatia de Graves sem os efeitos colaterais da prednisona.

Descritores: Oftalmopatia de Graves/quimioterapia; Colchicina/uso terapêutico; Prednisona/efeitos adversos; Tabagismo; Estudos prospectivos

\section{REFERENCES}

1. Heufelder AE, Weetman AP, Ludgate M, Bahn RS. Pathogenesis of Graves' ophthalmopathy. In: Prummel MF, editors. Recent developments in Graves' ophthalmopathy. Boston: Kluwer Academic Publishers; 2000. p.15-37.
2. Bartalena L, Pinchera A, Marcocci C. Management of Graves' ophthalmopathy: reality and perspectives. Endocr Rev. 2000;21(2):168-99.

3. Matos K, Nose VV, Manso PG, Ho RF, Marback E, Nakanami C, et al. Correlation Between Clinical and Histological Analysis in Retroocular Connective Tissues and Extraocular Muscles from Patients with Graves' Ophthalmopathy. Endocr Pathol. 2000;11(2):185-94.

4. Hayasaka S, Kawamoto K, Noda S, Kodama T. Visual prognosis in patients with Behcet's disease receiving colchicine, systemic corticosteroid or cyclosporin. Ophthalmologica. 1994;208(4):210-3.

5. Ben-Chetrit E, Levy M. Colchicine: 1998 update. Semin Arthritis Rheum. 1998;28(1):48-59.

6. Fordham JN, Kirwan J, Cason J, Currey HL. Prolonged reduction in polymorphonuclear adhesion following oral colchicine. Ann Rheum Dis. 1981;40 (6):605-8

7. Levy M, Spino M, Read SE. Colchicine: a state-of-the-art review. Pharmacotheraphy. 1991;11(3):196-211.

8. Caner JE. Colchicine inhibition of chemotaxis. Arthritis Rheum. 1965;8(5): 757-64.

9. Malawista SE, Bodel PT. The dissociation by colchicine of phagocytosis from increased oxygen consumption in human leukocytes. J Clin Invest. 1967;46(5):786-96.

10. Ding AH, Porteu F, Sanchez E, Nathan CF. Downregulation of tumor necrosis factor receptors on macrophages and endothelial cells by microtubule depolymerizing agents. J Exp Med. 1990;171(3):715-27.

11. Allen JN, Herzyk DJ, Wewers MD. Colchicine has opposite effects on interleukin-1 beta and tumor necrosis factor-alpha production. Am J Physiol. 1991;261(4 Pt 1):L315-21.

12. Molad Y, Reibman J, Levin RI, Cronstein BN. A new mode of action for an old drug: Colchicine decreases surface expression of adhesion molecule on both neutrophils (PMNs) and endothelium [abstract]. Arthritis Rheum. 1992; 35(9 Suppl):S1-377. [56th annual scientific meeting of the American College of Rheumatology. Atlanta, Georgia, October 11-15, 1992].

13. Freed BM, Lempert N, Lawrence DA. The inhibitory effects of N-ethylmaleimide, colchicine and cytochalasins of human T-cell functions. Int $\mathrm{J}$ Immunopharmacol. 1989;11(5):459-65.

14. Entzian P, Schlaak M, Seitzer U, Bufe A, Acil Y, Zabel P. Antiinflammatory and antifibrotic properties of colchicine: implications for idiopathic pulmonary fibrosis. Lung. 1997; 175(1):41-51.

15. Roberge CJ, de Medicis R, Dayer JM, Rola-Pleszczynski M, Naccache PH, Poubelle PE. Crystal-induced neutrophil activation. V. Differential production of biologically active IL-1 and IL-1 receptor antagonist. J Immunol. 1994;152(11):5485-94.

16. Stosic-Grujicic S, Simic MM. Modulation of interleukin 1 production by activated macrophages: in vitro action of hydrocortisone, colchicine, and cytochalasin B. Cell Immunol. 1982;69(2):235-47.

17. Kung AW, Michon J, Tai KS, Chan FL. The effect of somatostatin versus corticosteroid in the treatment of Graves' ophthalmopathy. Thyroid. 1996;6 (5):381-4.

18. Classification of eye changes of Graves' disease. Thyroid. 1992;2(3):235-6.

19. Mourits MP, Prummel MF, Wiersinga WM, Koornneef L. Clinical activity score as a guide in the management of patients with Graves' ophthalmopathy. Clin Endocrinol (Oxf). 1997;47(1):9-14.

20. Just M, Kahaly G, Higer HP, Rosler HP, Kutzner J, Beyer J, Thelen M. Graves ophthalmopathy: role of MR imaging in radiation therapy. Radiology. 1991;179(1):187-90.

21. Hiromatsu Y, Kojima K, Ishisaka N, Tanaka K, Sato M, Nonaka K, et al. Role of magnetic resonance imaging in thyroid-associated ophthalmopathy: its predictive value for therapeutic outcome of immunosuppressive therapy. Thyroid. 1992;2(4):299-305.

22. Moher D, Schulz KF, Altman DG. The CONSORT statement: revised recommendations for improving the quality of reports of parallel-group randomised trials. Lancet. 2001;357(9263):1191-4.

23. Schulz KF, Grimes DA. Generation of allocation sequences in randomised trials: chance, not choice. Lancet. 2002;359(9305):515-9.

24. Terwee CB, Gerding MN, Dekker FW, Prummel MF, Wiersinga WM. Development of a disease specific quality of life questionnaire for patients with Graves' ophthalmopathy: the GO-QOL. Br J Ophthalmol. 1998;82(7):773-9.

25. Smith TJ, Bahn RS, Gorman CA. Connective tissue, glycosaminoglycans, and diseases of the thyroid. Endocr Rev. 1989;10(3):366-91. Review.

26. Tan GH, Dutton CM, Bahn RS. Interleukin-1 (IL-1) receptor antagonist and soluble IL-1 receptor inhibit IL-1-induced glycosaminoglycan production in cultured human orbital fibroblasts from patients with Graves' ophthalmopathy. J Clin Endocrinol Metab. 1996;81(2):449-52. 
816 Colchicine in the treatment of the inflammatory phase of Graves' ophthalmopathy: a prospective and randomized trial with prednisone

27. Bahn RS, Heufelder AE. Pathogenesis of Graves' ophthalmopathy. N Engl J Med. 1993;329(20):1468-75. Review.

28. Carter JA, Utiger RD. The ophthalmopathy of Graves' disease. Annu Rev Med. 1992;43:487-95. Review.

29. Kahaly GJ, Rosler HP, Pitz S, Hommel G. Low-versus high-dose radiotherapy for Graves' ophthalmopathy: a randomized, single blind trial. J Clin Endocrinol Metab. 2000;85(1):102-8.

30. Gorman CA, Garrity JA, Fatourechi V, Bahn RS, Petersen IA, Stafford SL, et al. A prospective, randomized, double-blind, placebo-controlled study of orbita radiotherapy for Graves’ ophthalmopathy. Ophthalmology. 2001;108 (9):1523-34.

31. Gorman CA. Radiotherapy for Graves' ophthalmopathy: results at one year. Thyroid. 2002;12(3):251-5.

32. Reis AF, Oliveira TLP, Manso PG, Furlanetto RP. Oftalmopatia de Graves. Arq Bras Endocrinol Metab. 1995;39(3/4):131-40.

33. Prummel MF, Wiersinga WM. Immunomodulatory treatment of Graves' ophthalmopathy. Thyroid. 1998;8(6):545-8.

34. Debets R, Savelkoul HF. Cytokine antagonists and their potential therapeutic use. Immunol Today. 1994;15(10):455-8.
35. Gorman CA. Pathogenesis of Graves' ophthalmopathy. Thyroid. 1994;4(3): 379-83. Review.

36. Bartalena L, Marcocci C, Pinchera A. Cytokine antagonists: new ideas for the management of Graves' ophthalmopathy. J Clin Endocrinol Metab. 1996;81 (2):446-8.

37. Kershenobich D, Rojkind M, Quiroga A, Alcocer-Varela J. Effect of colchicine on lymphocyte and monocyte function and its relation to fibroblast proliferation in primary biliary cirrhosis. Hepatology. 1990;11(2):205-9.

38. Kunkel SL, Chensue SW, Phan SH. Prostaglandins as endogenous mediators of interleukin 1 production. J Immunol. 1986;136(1):186-92.

39. Perico N, Ostermann D, Bontempeill M, Morigi M, Amuchastegui CS, Zoja $\mathrm{C}$, et al. Colchicine interferes with L-selectin and leukocyte function-associated antigen-1 expression on human $\mathrm{T}$ lymphocytes and inhibits $\mathrm{T}$ cell activation. $\mathrm{J}$ Am Soc Nephrol. 1996;7(4):594-601.

40. Utiger RD. Pathogenesis of Graves' ophthalmopathy. N Engl J Med. 1992; 326(26):1772-3.

41. Wiersinga WM. Preventing Graves' ophthalmopathy. N Engl J Med. 1998; 338(2):121-2 